Kolaborasi : Jurnal Administrasi Publik, Desember 2019 Volume 5 Nomor 3

\title{
ANALISIS PEMBERDAYAAN MASYARAKAT DESA SRI TAJUNG KECAMATAN RUPAT KABUPATEN BENGKALIS
}

\author{
Firna Dianti ${ }^{1}$, Nahar Effendi ${ }^{2}$ \\ ${ }^{1,2}$ Ilmu Administrasi Negara, STIA Lancang Kuning Dumai
}

\begin{abstract}
Implementationof Community Empowerment in the Sri Tanjung Village in forming individuals and communities to become independent is still not maximized. Still lack of training and development of community groups in the Sri Tanjung Village. Based on these symptoms, the authors formulate the main problems in this study, namely: How is Community Empowerment in Sri Tanjung Village. The purpose of this study are: To find out Community empowerment in Sri Tanjung Village, and To find out supporting factors and inhibiting factors for Community Empowerment in Sri Tanjung Village. The approach used in this research is qualitative, in which the research procedure produces descriptive data of written or oral words. Data collection techniques used in interviews, with village heads including the community of the village of Sri Tanjung. Based on the analysis of researchers on community empowerment at the village office of Sri Tanjung, it can be concluded that there are supporting factors for the existence of Business Development which is one of the important things in providing an impact or benefit for improvement the economic welfare of the community and the presence of institutional development that also has an impact on improving the community's economy. While the inhibiting factors are still the lack of Community Development that can be seen still not going on mutual cooperation activities and environmental cleanliness routinely and the lack of Human Development where there are still no quality human resources so there are many opportunities that cannot be utilized by the community because of limited knowledge and

skills .
\end{abstract}

Keywords:. Community empowerment, human resources

\begin{abstract}
Abstrak
Pelaksanaan pemberdayaan Masyarakat pada Desa Sri Tanjung dalam membentuk individu dan masyarakat menjadi mandiri masih belum maksimalnya.Masih kurangnya pelatihan dan pembinanterhadap kelompok-kelompok masyarakat yang ada di Desa Sri Tanjung.Berdasarkan gejala tersebut, maka penulis merumuskan masalah pokok dalam penelitian ini, yaitu: Bagaimana pemberdayaan Masyarakat pada Desa Sri Tanjung.Tujuan penelitian ini adalah: Untuk mengetahui pemberdayaan Masyarakat pada Desa Sri Tanjung,dan Untuk mengetahui faktor pendukung dan faktor penghambat Pemberdayaan Masyarakat pada Desa Sri Tanjung. Pendekatan yang digunakan dalam penelitian ini adalah kulitatif, dimana prosedur penelitian ini menghasilkan data deskriptif kata-kata tertulis atau lisan. Teknik pengumpulan data yang digunakan wawancara,dengan kepala desa termasuk masyarakt desa Sri Tanjung.Berdasarkan hasilanalisis peneliti tentang pemberdayaan masyatrakat pada kantor desa Sri Tanjung, dapat disimpulkan bahwa ada Faktor pendukung terdapatnya Bina Usaha yang menjadi salah satu hal penting dalam memberikan dampak atau manfaat bagi perbaikan kesejahteraan perekonomian masyarakat dan terdapatnya Bina kelembagaan yang juga memberikan dampak terhadap peningkatan perekonomian masyarakat. Sedangkan yang menjadi faktor penghambat Masih kurangnya Bina Lingkungan yang bisa dilihat masih belum berjalannya kegiatan gotong royong serta kebersihan lingkungan secara rutin dan masih kurangnya Bina Manusia di mana masih belum tersedianya sumberdaya manusia yang berkualitas sehingga banyak peluang yang tidak bisa dimanfaatkan masyarakat karena keterbatasan pengetahuan dan keterampilan.

Kata kunci: Pemberdayaan masyarakat, sumber daya manusia
\end{abstract}

Website : http://iournal.unismuh.ac.id/index.php/kolaborasi 


\section{PENDAHULUAN}

Pemberdayaan merupakan kegiatan terencana dan kolektif dalam memperbaiki kehidupan masyarakat yang dilakukan melalui program peningkatan kapasitas orang, terutama kelompok lemah atau kurang beruntung (Disadvantaged groups) agar mereka memiliki kemampuan dalam memenuhi kebutuhan dasarnya, mengemukakan gagasan, melakukan pilihan-pilihan hidup, melaksanakan kegiatan ekonomi, menjangkau dan memobilisasi sumber, berpartisipasi dalam kegiatan sosial (Suharto, 2009: 112).

Menurut (Sumodiningrat, 2009) pemberdayaan adalah proses meningkatkan kemampuan masyarakat dalam memanfaatkan sumber daya yang dimiliki dan yang tersedia di lingkungan sekitarnya untuk meningkatkan kesejahteraan. Menurut (Payne, 1997: 266) pemberdayaan adalah upaya membantu klien (masyarakat/ individu) untuk mendapatkan kekuatan/ kekuasaan dalam mengambil/ membuat keputusan untuk menentukan pilihan yang terbaik dalam kehidupan. Dilakukan dengan meningkatkan kapasitas dan kepercayaan dirinya dengan kata lain sebagai usaha untuk mengembangkan diri mereka/lingkungan secara optimal.

$$
\text { Development Center (1995:73) }
$$

menyatakan bahwa pemberdayaan tidak sekedar merupakan proses perubahan perilaku pada diri seseorang, tetapi merupakan proses perubahan sosial, yang mencakup banyak aspek, termasuk politik dan ekonomi yang dalam jangka panjang secara bertahap mampu diandalkan menciptakan pilihan-pilihan baru untuk memperbaiki kehidupan masyarakat.

Pemberdayaan masyarakat merupakan pendekatan yang memperhatikan seluruh aspek kehidupan masyarakat dengan sasaran seluruh lapisan masyarakat, bermotifkan pemandirian (keberdikarian), sehingga mampu membangkitkan kemampuan self-help. untuk meningkatkan kualitas hidup masyarakat (modernisasi) yang mengacu pada cara berpikir, bersikap, berperilaku untuk maju. Maka bidang pemberdayaan merupakan titik strategis yang harus diperbarui dan diperluas. Sehingga esensi pemberdayaan masyarakat di pedesaan adalah pendayagunaan sumberdaya (potensi) lokal, meningkatkan partisipasi, memupuk kepedulian semua pihak untuk kemandirian (berdikari) masyarakat (Suharto, 2018).

Salah satu konsepsi dan paradigma yang saat ini cukup populer dikembangkan adalah melalui pemberdayaan masyarakat. Sebagaimana yang telah diatur dalam undang-undang No 6 Tahun 2014 tentang Desa pada Bab 1 pasal 1 ayat 12 yakni pemberdayaan masyarakat Desa adalah upaya mengembangkan kemandirian dan kesejahteraan masyarakat dengan meningkatkan pengetahuan, sikap, keterampilan, perilaku, kemampuan, kesadaran, serta memanfaatkan sumber daya melalui penetapan kebijakan, program, kegiatan, dan pendampingan uang sesuai dengan esensi masalah dan prioritas kebutuhan masyarakat Desa.

Berlakunya UU desa tersebut sebagai otonomi bagi desa dan pembangunan yang 
bersifat partisipatif yang sudah intens menjadi konsep dan kajian akademis. Sebagaimana menurut Adi(2013) bahwa pembangunan di Indonesia akan kurang mempunyai arti bila tidak dilakukan pembangunan masyarakat desa' karena disadari masih cukup banyak desa yang belum dikembangkan secara optimal. Syahyuti (2006) konsep pembangunan partisipatif (participatory development) adalah proses yang melibatkan masyarakat secara aktif dalam seluruh keputusan substansial yang berkenaan dengan kehidupan. Rangkuti (2011) bahwa paradigma pembangunan saat ini mengalami pergeseran dimana pembangunan menekankan pada pemberdayaan (empowerment) yang dikenal dengan pembangunan manusia (people centered development)' pembangunan berbasis sumber daya lokal (resource based development) dan pembangunan kelembagaan (intitutional development).

Proses pembangunan yang melibatkan masyarakat dimaksudkan untuk pengembangan masyarakat yang biasa dikenal dengan konsep pemberdayaan (empowerment) masyarakat. Dimana tujuannya untuk membentuk individu dan masyarakat yang lebih mandiri. Kemandirian masyarakat tersebut meliputi kemandirian berfikir, kemandirian untuk bertindak serta kemandirian dalam mengendalikan sesuatu yang mereka kerjakan atau lakukan (Ambar teguh 2004).

Tujuan Pemberdayaan menurut World Bank (2001) meliputi: (1) perbaikan pendidikan (better education). Perbaikan pendidikan harus mampu menumbuhkan semangat belajar seumur hidup.
Perbaikan aksesibilitas (better accessibility), dengan tumbuh dan berkembangnya semangat belajar seumur hidup diharapkan dapat memperbaiki aksesibilitasnya. Terutama tentang aksesibilitas sumber: informasi/inovasi, pembiayaan, penyediaan produk dan peralatan, dan lembaga pemasaran. (3) Perbaikan tindakan (better action), dengan berbekal perbaikan pendidikan dan aksesibilitas dengan beragam sumber daya yang baik, diharapkan akan terjadi perubahan pada tindakan yang lebih baik. (4) Perbaikan kelembagaan (better institution), dengan perbaikan tindakan yang dilakukan diharapkan dapat memperbaiki kelembagaan, termasuk pengembangan jejaring kemitraan usaha. (5) Perbaikan usaha (better business), dengan perbaikan pendidikan (semangat belajar) aksesibilitas kegiatan, dan perbaikan kelembagaan diharapkan dapat memperbaiki bisnis yang dilakukan. (6) Perbaikan pendapatan (better income), dengan perbaikan bisnis maka mereka dapat memperoleh pendapatan untuk bisnis dan termasuk untuk keluarga serta masyarakat.

(7) Perbaikan lingkungan (better environment), perbaikan pendapatan diharapkan dapat memperbaiki lingkungan fisik dan sosial, karena kerusakan lingkungan seringkali disebabkan oleh kemiskinan dan pendapatan yang terbatas. (8) Perbaikan kehidupan (better living), dengan tingkat pendapatan dan keadaan lingkungan yang membaik, diharapkan dapat memperbaiki kondisi setiap keluarga dan masyarakat. (9) Perbaikan masyarakat (better community), dengan kehidupan yang lebih baik didukung oleh lingkungan (fisik 
Kolaborasi : Jurnal Administrasi Publik, Desember 2019 Volume 5 Nomor 3

dan sosial) yang lebih baik diharapkan terwujud kehidupan masyarakat lebih baik.

Pemberdayaan memiliki dua kecenderungan, yaitu pemberian kekuatan serta kekuasaan terhadap individu dan motivasi serta menstimulasi kemampuan. Di dalam kegiatan pemberdayaan secara umum mencakup; perumusan relasi kemitraan, mengartikulasikan tantangan-tantangan dan mengidentifikasi kekuatan, mendefinisikan arah yang ditetapkan dan mengeksplorasi sistem-sistem sumber (Hikmat, 2010: 10).

Untuk mewujudkan pemberdayaan yang baik maka, dapat dilakukan dengan memanfaatkan potensi yang ada dan dimiliki oleh masyarakat sekitar seperti alam, sosial, budaya dan sebagainya. Pemanfaatan aset tersebut penting karena pemberdayaan memang pada dasarnya adalah proses meningkatkan kemampuan masyarakat dalam memanfaatkan sumber daya yang dimiliki dan tersedia di lingkungan sekitar untuk meningkatkan kesejahteraan (Halpern, 2005).

Ketidak berdayaan masyarakat secara sosial dan ekonomi menjadi salah satu ganjalan bagi masyarakat untuk berdiri sama tinggi dan duduk sama rendah dengan sesama saudaranya yang telah berhasil.Kondisi inilah yang perlu dipahami dan dijadikan salah satu pertimbangan dalam pengambilan kebijakan dan perencanaan penyusunan program, agar pengelolaan setiap kebijakan dapat memperhatikan kondisi sosial budaya dan ekonomi masyarakat sekitar.

Paradigma perencanaan dan pengelolaan pemberdayaan masyarakat yang sentralistik dimana program dirancang dari atas tanpa melibatkan masyarakat, harus di ubah kearah peningkatan partisipasi masyarakat lokal secara optimal. Pemberdayaan dapat diartikan sebagai suatu pelimpahan atau pemberian kekuatan (power) yang akan menghasilkan hirarkikekuatan agar mampu mengelola potensi-potensi yang ada untuk dimanfaatkan sebaik mungkin(Kesi,2011). Berkaitan dengan hal ini, Sumodiningrat (2000) menjelaskan bahwa keberdayaan masyarakat yang ditandai adanya kemandiriannya dapat dicapai melalui proses pemberdayaan masyarakat.

Pemerintahan Desa dipimpin oleh kepala Desa untuk penyelengaraan urusan pemerintahan dan kepentingan masyarakat dalam sistem pemerintahan Negara Kesatuan Republik Indonesia. Kepala Desa selaku pemerintah di sebuah Desa bertugas menyelengarakan pemerintahan Desa, melaksanakan pembangunan Desa, pembinaan kemasyarakatan Desa dan pemberdayaan masyarakat Desa. Pemerintah Desa bekerja sama dengan pemerintah Kecamatan dalam melaksanakan upaya pemberdayaan melalui Dinas yang terdapat di Kecamatan, yang mana pemerintah Desa membantu dalam mengusulkan usulan program-program di Kecamatan.

Peran Pemerintah Desa selaku pendamping (fasilitator), pada intinya merupakan suatu bentuk inisiatif, prakarsa, komitmen, kepedulian, motivasi, keputusan dan ikhtiar dari masyarakat berbasis pada nilai-nilai luhur dan kebutuhan masyarakat. Peran pendamping pada pelaksanaan program berkewajiban melakukan proses pembelajaran masyarakat agar mereka mampu malakukan tahapan kegiatan 
program tersebut atas dasar kesadaran kritis terhadap substansi mengapa dan untuk apa suatu kegiatan itu dilakukan.

Desa Sri Tanjung merupakan salah satu desa yang berada dalam wilayah Kecamatan Rupat Kabupaten Bengkalis hasil pemekaran dari Desa Teluk Lecah. Dasar hukum pembentukan Desa Sri Tanjung berdasarkan Perda Kabupaten Bengkalis No. 12 Tahun 2012 tentang pembentukan desa, desa baru hasil pemekaran desa di Kabupaten Bengkalis. Di mana memiliki jumlah penduduk terhitung Pada tahun 2019 berjumlah 1.392 jiwa atau sama dengan 261 kepala keluarga (KK).(Wawancara, 20 september 2019).

Pemerintah Desa yang terdiri dari

Kepala Desa, Sekretaris Desa, Perangkat Desa dan unsur lainnya merupakan satuan kerja yang langsung bersentuhan dengan kepentingan masyarakat kalangan bawah (Agus,2016). Sebagai seorang Kepala Desa, mempunyai tanggung jawab yang cukup besar dalam mengemban amanah terhadap masyarakat, yakni salah satunya berkaitan dengan mensejahterakan kehidupan masyarakat dengan cara memanfaatkan sumber daya yang ada untuk di tumbuh kembangkan kembali (diberdayakan). Dalam kegiatan pemberdayaan ada pihak yang melakukan pemberdayaan terhadap masyarakat yaitu: Aparatur pemerintah yang bertugas dilapangan,seperti perangkat Desa dan UPTD (Unit Pelaksana Teknis Daerah) (Sandhi,2014)

Program pemberdayaan masyarakat pada Desa Sri Tanjung sekurang-kurangnya harus menghasilkan masyarakat yang peduli dengan kemiskinan dan pelestarian lingkungan serta mampu mengaktualisasikan dirinya sebagai bagian dari upaya penanggulangan kemiskinan serta mampu membentuk lembaga kesewadayaan masyarakat yang di percaya, aspiratif dan akuntabel. Pemberdayaan dapat dilakukan oleh masyarakat maupun pemerintah setempat dalam upaya peningkatan kualitas kesejahteraan masyarakat meliputi kesejahteraan keluarga, memandirikan masyarakat miskin, mengangkat harkat dan martabat masyarakat lapisan bawah.

Menurut Suparjan dan Hempri S (2003:44), bahwa dalam memberdayakan masyarakat dibutuhkan tahap pemberdayaan yang jelas dan terarah, dalam rangka pemberdayaan masyarakat ada beberapa hal yang harus dilakukan antara lain:

1. Meningkatkan kesadaran kritis atau posisi masyarakat dalam struktur sosial politik. Hal ini berangkat dari asumsi bahwa sumber kemiskinan berasal dari konstruksi sosial yang yang ada pada masyarakat itu sendiri

2. Kesadaran kritis yang muncul diharapkan membuat masyarakat mampu membuat argumentasi terhadap berbagai macam aksploitasi serta sekaligus membuat pemutusan terhadap hal tersebut

3. Peningkatan kapasitas masyarakat. Dalam konteks ini perlu dipahami bahwa masalah kemiskinan bukan sekedar persoalan kesejahteraan sosial tetapi berkaitan dengan faktor politik, ekonomi sosial budaya dan keamanan

4. Pemberdayaan juga perlu meningkatkan dengan pembangunan sosial budaya masyarakat. 
Kolaborasi : Jurnal Administrasi Publik, Desember 2019 Volume 5 Nomor 3

Untuk mencapai tujuan tersebut, perlu diciptakan suatu program pemberdayaan dipedesaan sehingga mampu mensejahterakan keluarga dan masyarakat. Program pemberdayaan bisa dilakukan dengan menciptakan lapangan pekerjaan maupun kelompok-kelompok tertentu (Rili Windiasih dan Toto Sugito 2018) . Dalam hal ini diperlukan pembinaan-pembinaan dan pelatihan-pelatihan oleh lembagalembaga pemerintah maupun instansi terkait kepada masyarakat dalam upaya meningkatkan keterampilan dan kesejahteraan kualitas hidupnya serta memotivasi dalam membangun kebersamaan dan kerjasama antar kelompok dengan membentuk gabungan kelompok sebagai sebagai embrio untuk membentuk koperasi dan menyusun suatu kekuatan serta koordinasi dalam mengelola suatu usaha.

Menjelaskan usulan sarana prasarana pendukung pemberdayaan masyarakat yang diusulkan oleh Kepala Desa masih belum terealisasi sesuai dengan yang diharapkan yang mana terlihat bahwa dalam usulan sarana prasarana Kepala Desa Sri Tanjung yaitu, Untuk usulan jaring udang sebanyak 90 keping yang terealisasi berjumlah 40 keping dan 50 keping tidak terealisasi, mesin giling kopi 1 unit namun tidak terealisasi, timbangan bayi dari 2 unit yang terealisasi 1 unit dan 1 unit tidak terealisasi,baju kompang 80 set tidak terealisasi sama sekali, perlengkapan rebana sebanyat 1 set namun tidak terealisasi, komputer 5 unit tidak terealisasi, pengadaan pupuk $100 \mathrm{~kg}$ hanya $50 \mathrm{~kg}$ terealisasi dan $50 \mathrm{~kg}$ tidak terealisasi, mesin jahit 20 unit tidak teralisasi, tong air 90 unit hanya 60 terealisasi dan 30 tidak terealisasi (Wawancara, 20 september 2019)..

Untuk dapat melihat kegiatan pada kelompok-kelompok pemberdayaan masyarakat Desa Sri Tanjung Kecamatan Rupat Kabupaten Bengkalis dapat di lihat pada tabel di bawah ini:

Tabel I.1

Jenis dan Jumlah Anggota Kelompok Pemberdayaan Serta Kegiatan Pelatihan Yang Dilakukan di Desa Sri Tanjung

\begin{tabular}{clcl}
\hline No & $\begin{array}{c}\text { Kelompok Yang } \\
\text { Diberdayakan }\end{array}$ & $\begin{array}{c}\text { Jumlah } \\
\text { Anggota }\end{array}$ & \multicolumn{1}{c}{ Kegiatan dan Penyuluhan Yang Diikuti } \\
\hline 1 & $\begin{array}{l}\text { Kelompok Petani } \\
(2 \text { kelompok })\end{array}$ & 50 orang & $\begin{array}{l}\text { Cara pemupukan, Pemeliharaan tanaman,SL- } \\
\text { PHT, pengairan }\end{array}$ \\
\hline 2 & $\begin{array}{l}\text { Kelompok Nelayan } \\
(2 \text { kelompok })\end{array}$ & 42 orang & $\begin{array}{l}\text { Cara penangkapan ikan yang benar, } \\
\text { memanfaatkat hasil tangkapan dijadikan olahan } \\
\text { kerupuk dan aturan kelautan. Dan Iklim yang } \\
\text { tepat untuk melaut. }\end{array}$ \\
\hline
\end{tabular}


Kolaborasi : Jurnal Administrasi Publik, Desember 2019 Volume 5 Nomor 3

\begin{tabular}{|c|c|c|c|}
\hline 3 & $\begin{array}{l}\text { Posyandu } \\
\text { ( } 3 \text { kelompok ) }\end{array}$ & 20 orang & $\begin{array}{l}\text { Penyuluhan program kesehatan, Imunisasi, Cek } \\
\text { kesehatan bayi dan ibu hamil, perkembangan } \\
\text { berat badan bayi, Mengenal HIV/AIDS, Cek } \\
\text { kesehatan lansia, penyuluhan KB. }\end{array}$ \\
\hline 4 & $\begin{array}{l}\text { PKK } \\
(1 \text { kelompok ) }\end{array}$ & 24 orang & $\begin{array}{l}\text { Senam sehat, Keagamaan, Pengolahan kopi, } \\
\text { Kegiatan sosial, Pola penanaman dan menjaga } \\
\text { kesuburan tanah, Kegiatan pokja, Pengolahan } \\
\text { kerupuk ubi }\end{array}$ \\
\hline 5 & $\begin{array}{l}\text { Kompang } \\
\text { ( } 3 \text { kelompok ) }\end{array}$ & 45 orang & $\begin{array}{l}\text { Adat istiadat perkawinan, acara keagamaan, } \\
\text { acara-acara resmi, tata cara menyanyikan lagu } \\
\text { kompang dengan benar. }\end{array}$ \\
\hline 6 & $\begin{array}{l}\text { Karang Taruna } \\
(1 \text { kelompok ) }\end{array}$ & 16 orang & $\begin{array}{l}\text { Olahraga, sosial, pendidikan, kepemudaan, tata } \\
\text { cara pengurusan, manajemen organisasi }\end{array}$ \\
\hline 7 & $\begin{array}{l}\text { Rebana } \\
(2 \text { kelompok ) }\end{array}$ & 36 orang & $\begin{array}{l}\text { Melestarikan dan memelihara lagu-lagu yang } \\
\text { bernuansa islami, membina generasi muda } \\
\text { dalam mengembangkan rebana, pentingnya } \\
\text { menjaga dan mempertahankan budaya rebana. }\end{array}$ \\
\hline & Jumlah & 233 & \\
\hline
\end{tabular}

Sumber Data ; Desa Sri Tanjung Tahun2019

Untuk dapat melihat kegiatan pada kelompok-kelompok pemberdayaan masyarakat desa Sri Tanjung dapat dilihat dari pada jenis-jenis kelompok pemberdayaan yang ada pada Desa Sri Tanjung serta akan dijelaskan nama dan jumlah anggota kelompok pemberdayaan serta kegiatan dan penyuluhan yang dilakukan. Pada Kelompok Petani terdapat 50 jumlah anggota yang mana kegiatan dan pelatihan berkaitan dengan penanaman, pemeliharaan tanaman, (sekolah lapanganpengendalian hama terpadu), pada Kelompok Nelayan berjumlah 42 anggota kelompok yang mana kegiatan dan penyuluhan berkaitan penangkapan Ikan dengan cara yang baik, serta memanfaatkat hasil tangkapan dijadikan olahan kerupuk dan aturan kelautan.Selanjutnya pada
Kelompok PKK terdapat 24 jumlah anggota yang melakukan kegiatan dan pelatihan mengenai pemanfaatan barang bekas, kerupuk ubi dan aneka olahan lainnya. Pada Posyandu Terdapat 20 anggota kelompok dan mengikuti kegiatan imunisasi, penyuluhan program kesehatan, penyuluhan $\mathrm{KB}$, dan perkembangan gizi anak. Kompang berjumlah 45 anggota kelompok yang mengikuti kegiatan adat istiadat perkawinan dan acara keagaamaan serta acara-acara resmi.Karang Taruna berjumlah 16 orang yang melakukan kegiatan olahraga, sosial, kepemudaan, pendidikan.Rebana berjumlah 36 anggota kelompok yang memiliki kegiatan memelihara dan melestarikan lagulagu bernuansa islami dan membina generasi muda untuk mengembangkan budaya rebana.

\section{Website : $\underline{\text { http://journal.unismuh.ac.id/index.php/kolaborasi }}$}


Kolaborasi : Jurnal Administrasi Publik, Desember 2019 Volume 5 Nomor 3

Margono Slamet (2000) Menegaskan bahawa inti dari kegiatan penyuluhan adalah untuk memberdayakan masyarakat. Memberdayakan berarti memberi daya kepada yang tidak berdaya atau mengembangkan daya yang sudah dimiliki menjadi sesuatu yang lebih bermanfaat bagi masyarakat yang bersangkutan. Margono Slamet (2000) menekankan esensi penyuluhan sebagai kegiatan pemberdayaan masyarakat yang telah mulai lazim digunakan oleh banyak pihak sejak Program Pengentasan Kemiskinan pada awal dasawarsa 1990-an. Penyuluhan pembangunan sebagai proses pemberdayaan masyarakat, memiliki tujuan utama yang tidak terbatas pada terciptanya "betterfarming, better business, dan better living, tetapi untuk memfasilitasi masyarakat (sasaran) untuk mengadopsi strategi produksi dan pemasaran agar mempercepat terjadinya perubahan-perubahan kondisi sosial, politik dan ekonomi sehingga mereka dapat (dalam jangka panjang) meningkatkan taraf hidup pribadi dan masyarakatnya. Untuk melihat pelatihan dan pembinaan kelompok masyarakat Desa Sri Tanjung Kecamatan RupatKabupaten Bengkalis dapat di lihat pada tabel di bawah ini:

Tabel I.2

Program Pelatihan Dan PembinaanPada KelompokKelompok Yang Ada di Desa Sri Tanjung Kecamatan Rupat Kabupaten Bengkalis

\begin{tabular}{|c|c|c|c|c|c|c|c|}
\hline \multirow{2}{*}{ No } & \multirow{2}{*}{$\begin{array}{c}\text { Program } \\
\text { pelatihan dan } \\
\text { pembinaan }\end{array}$} & \multicolumn{2}{|c|}{2017} & \multicolumn{2}{|c|}{2018} & \multicolumn{2}{|c|}{2019} \\
\hline & & target & $\begin{array}{c}\text { Realisas } \\
\mathrm{i}\end{array}$ & target & realisasi & target & Realisasi \\
\hline 1 & $\begin{array}{l}\text { Kelompok } \\
\text { Nelayan }\end{array}$ & - & - & 1 & - & 1 & - \\
\hline 2 & $\begin{array}{l}\text { Kelompok } \\
\text { Tani }\end{array}$ & 3 & 1 & 2 & 1 & - & - \\
\hline 3 & PKK & 3 & 3 & 1 & - & 1 & - \\
\hline 4 & Posyandu & 2 & 2 & 2 & 1 & 1 & 1 \\
\hline 5 & Kompang & 1 & - & 1 & 1 & 1 & - \\
\hline 6 & $\begin{array}{l}\text { Karang } \\
\text { taruna }\end{array}$ & 1 & 1 & 1 & - & 1 & 1 \\
\hline 7 & Rebana & 1 & 1 & 2 & - & 2 & - \\
\hline
\end{tabular}

Sumber Data : Desa Sri Tanjung Tahun 2019

Hal tersebut menjelaskan bahwa kegiatan pelatihan dan pembinaan dalam pemberdayaan masyarakat pada Desa Sri Tanjung masih belum berjalan secara merata atau masih belum maksimal yang dimana dalam hal ini bisa dilihat padaprogram pelatihan dan pembinaan pada kelompokkelompok pemberdayaan yang ada di Desa Sri Taanjung yakni: Pada kelompok Nelayan daritahun 2017 sampai 2019 dari 2 target namun tidak terealisasi sama sekali. Pada Kelompok Tani pada tahun 2017 sebanyak 3 Website : http://journal.unismuh.ac.id/index.php/kolaborasi 
Kolaborasi : Jurnal Administrasi Publik, Desember 2019 Volume 5 Nomor 3

target namun hanya 1 kali yang terealisasi dan pada tahun 2018 sebanyak 2 target namun hanya 1 kali yang terealisasi. Pada kelompok PKK tahun 2017 sebanyak 3 target dan terealisasi, pada tahun 2018 dan 2019 dari masing-masing 1 target namun tidak terealisasi. Sedangkan pada kelompok Posyandu pada tahun 2017 sebanyak 2 target dan terealisasi, tahun 2018 dari 2 target yang terealisasi hanya 1 kali dan pada tahun 2019 sebanyak 1 target dan terealisasi. Pada Kompang tahun 2017 sebanyak 1 target namun tidak terealisasi, pada tahun 2018 sebanyak 1 target dan terealisasi dan tahun 2019 tidak terealisasi. Untuk Karang Taruna pada tahun 2017 sebanyak 1 kali dan terealisasi pada tahun 2018 sebanyak 1 target namun tidak terealisasi dan tahun 2019 hanya 1 target dan terealisasi. Untuk Rebana pada tahun 2017 sebanyak 1 target dan terealisasi dan tahun 2018 dan 2019 dari 2 target masing-masingnamun tidak ada yang terealisasi.

\section{METODE PENELITIAN}

Penelitian yang digunakan oleh peneliti bersifat deskriptif kualitatif. Informan penelitian ini adalah masyarakat yang berdomisili di Desa Sri Tanjung Berdasarkan data survei diperoleh 15 orang informan, Informan lainnya adalah Ketua RT/RW Desa Sri Tanjung Kecamatan Rupat Kabupaten Bengkalis.

Sumber data dalam penelitian ini menggunakan sumber data primer dan data sekunder. penelitian ini menggunakan metode deskriptif kualitatif.

\section{HASIL DAN PEMBAHASAN}

Pemberdayaan merupakan implikasi dari strategi pembangunan yang berbasis pada masyarakat (people centred development).Terkait dengan pembangunan, apapun pengertian yang diberikan terhadapnya selalu merujuk pada upaya perbaikan, terutama perbaikan pada mutu hidup manusia, baik secara fisik, mental, ekonomi maupun sosial budayanya.

Salah satu konsepsi dan paradigma yang saat ini cukup populer dikembangkan adalah melalui pemberdayaan masyarakat. Pemberdayaan masyarakiat pada dasarnya bertujuan mewujudkan kesejahteraan, kedaulatan, kemandirian serta untuk melibatkan masyarakat dalam pelaksanaannya sebagaimana makna dari otonomi daerah yang di atur dalam penyelenggaraan Pemerintahan daerah yang telah diamanatkan Undang-Undang Nomor 23 Tahun 2014 tentang Pemerintahan Daerah pada prinsipnya mengubah sistem penyelenggaraan pemerintahan daerah,sehingga daerah diarahkan untuk mempercepat terwujudnya kesejahteraan masyarakat dengan meningkatkan pelayanan, pemberdayaan dan peran masyarakat.

Kemandirian masyarakat marupakan suatu kondisi yang dialami oleh masyarakat yang ditandai dengan kemampuan memikirkan, memutuskan serta melakukan sesuatu yang dipandang tepat demi mencapai pemecahan masalah-masalah yang dihadapi dengan mempergunakan daya kemampuan yang dimiliki. Daya kemampuan yang dimaksud adalah kemampuan kognitif, konatif psikomotorik dan afektif serta sumber daya lainya yang 
bersifat fisik atau material. Untuk mewujudkan suatu masyarakat yang mandiri tentu memerlukan sebuah proses belajar. Masyarakat yang mengikuti proses belajar yang baik, secara bertahap akan memperoIeh daya, kekuatan ataukemampuan yang bermanfaat dalam proses pengambilan keputusan secara mandiri.

Sasaran utama pemberdayaan masyarakat adalah mereka yang lemah dan tidak memiliki daya, kekuatan atau kemampuan mengakses sumberdaya produktif atau masyarakat yang terpinggirkan dalam pembangunan, proses pemberdayaan masyarakat bertujuan untuk memandirikan warga masyarakat agar dapat meningkatkan taraf hidup keluarga dan mengoptimalkan sumberdaya yang di milikinya. Ketidak berdayaan masyarakat secara sosial dan ekonomi menjadi salah satu ganjalan bagi masyarakat untuk berdiri sama tinggi dan duduk sama rendah dengan sesama saudaranya yang telah berhasil. Kondisi inilah yang perlu di pahami dan dijadikan salah satu pertimbangan dalam pengambilan kebijakan dan perencanaan penyusunan program, agar pengelolaan setiap kebijakan dapat memperhatikan kondisi sosial budaya dan ekonomi masyarakat sekitar.

Paradigma perencanaan dan pengelolaan pemberdayaan masyarakat yang sentralistik dimana program dirancang dari atas tanpa melibatkan masyarakat, harus di ubah kearah peningkatan partisipasi masyarakat lokal secara optimal. Pemberdayaan dapat diartikan sebagai suatu pelimpahan atau pemberian kekuatan (power) yang akan menghasilkan hirarkikekuatan agar mampu mengelola potensi-potensi yang ada untuk dimanfaatkan sebaik mungkin.

Pada hakikatnya pemberdayaan merupakan upaya untuk menjadikan masyarakat menjadi lebih berdaya dan berkemampuan sehingga mereka dapat mewujudkan potensi serta kemampuan yang mereka miliki. Dalam proses pemberdayaan biasanya ada yang di sebut subyek dan obyek. Subyek adalah orang atau kelompok yang memberdayakan, sedangkan obyek adalah orang atau kelompok yang diberdayakan.

Sehubungan dengan penelitian yang penulis lakukan dengan judul Analisis Pemberdayaan Masyarakat pada Desa Sri Tanjung Kecamatan Rupat Kabupaten Bengkalis maka penulis akan mengukur:

1. Bina Manusia

Langkah awal dari suatu keberhasilan sebuah organisasi adalah adanya sikap serta keterampilan yang baik dari para anggota organisasi.Sikap dan keterampilan yang baik berawal dari adanya bentuk pembinaan manusia.Hal ini di landasi oleh pemahaman bahwa tujuan pembangunan adalah untuk perbaikan mutu hidup atau kesejahteraan manusia.

Bina manusia bertujuan untuk meningkatkan kreatifitas dan investasi pada modal manusia (human capital) yaitu dalam bidang pendidikan dan kesehatan, Peningkatan kapasitas organisasi dan kelompok baik formal maupun informal sebagai suatu cara untuk mensinergikan dan memadukan kekuatan individu, memperluas dan mengintegrasikan kelompok sehinggaefisiensi bisa tercapai. Memperbaiki budaya kerja keras, tanggung 
Kolaborasi : Jurnal Administrasi Publik, Desember 2019 Volume 5 Nomor 3

jawab, hemat, menghilangkan sifat mental negatif, boros dan menghambat pembangunan.

Manusia merupakan unsur pertama dan utama yang perlu di perhatikan dalam setiap upaya pemberdayaan masyarakat karena manusia merupakan pelaku atau pengelola pemberdayaan tersebut.Untuk itu diperlukan sebuah pembinaan manusia yang bertujuan untuk meningkatkan keterampilan, kreatifitas dan pengembangan kapasitas individu.

2. Bina Usaha

Bina usaha adalah upaya peningkatan pengetahuan teknis, perbaikan manajemen untuk meningkatkan efisiensi usaha dan mengembangkan jiwa kewirausahaan masyarakat. Bina usaha juga merupakan peningkatkan keterampilan usaha, pengelolaan bisnis skala kecil dan pengusaha teknologi, Meningkatkan dan mempermudah akses terhadap teknologi, modal, pasar, informasi pembangunan, membangun kemitraan mutualistis di antara sesama pelaku ekonomi rakyat melalui kerjasama perusahaan usaha besar, membangun sistem insentif administrasi serta pendanaan formal dan informal.

3. Bina Lingkungan

Bina lingkungan merupakan upaya melestarikan sumber daya alam yang ada di sekitar masyarakat. Bina lingkungan ialah upaya Meningkatkan peran masyarakat dalam mengelola dan menata lingkungan hidup, baik tempat tinggal mereka maupun habitat atau kawasan tempat kegiatan ekonomi produktif dijalankan, membangun infrastruktur terutama menyangkut dengan kebutuhan-kebutuhan masyarakat dalam melaksanakan kegiatan ekonomi, meningkatkan perencanaan dan pembangunan secara spasial dan daya dukung lingkungannya, meningkatkan kualitas lingkungan hidup melalui konservasi, rehabilitasi, reboisasi dan lain sebagainya.

4. Bina Kelembagaan

Kelembagaan adalah suatu hubungan dan tatanan antara anggota masyarakat atau organisasi yang melekat di wadahi dalam suatu jaringan atau organisasi yang dapat menentukan suatu hubungan antara manusia atau organisasi dengan ditentukan oleh faktor-faktor pembatas dan pengikat berupa norma, kode etik atau aturan formal dan non-formal untuk berkerjasama demi mencapai tujuan yang diinginkan. Kelembagaan berisi sekelompok orang yang bekerjasama dengan pembagian tugas tertentu untuk mencapai suatu tujuan yang diinginkan.Tujuan peserta kelempok dapat berebeda, tetapi dalam organisasi menjadi satu kesatuan.Kelembagaan lebih ditekankan pada aturan main (the rules) dan kegiatan kolektif (collective action) untuk mewujudkan kepentingan umum atau bersama.

Beberapa unsur penting dalam kelembagaan adalah isntitusi yang merupakan landasan untuk membangun tingkah laku sosial masyarakat, norma tingkah laku yang telah mengakar pada kehidupan masyarakat dan telah di terima untuk mencapai tujuan tertentu, peraturan dengan penegakan aturan dalam masyarakat yang memberikan wadah koordinasi dan kerjasama dengan dukungan hak dan kewajiban serta tingkah laku anggota, kode etik, kontrak serta insentif. 
Faktor pendukung dan Faktor Penghambat Pemberdayaan Masyarakat Pada Desa Teluk Lecah Kecamatan Rupat Kabupaten Bengkalis

Setelah melakukan penelitian terhadap Analisis Pemberdayaan Masyarakat Pada Desa Sri Tanjung Kecamatan Rupat Kabupaten Bengkalis, penulis menemukan beberapa faktor pendukung dan penghambat yang dapat dijelaskan sebagai berikut:

1. Faktor Pendukung

Berdasarkan hasil penelitian terhadap Pemberdayaan Masyarakat Pada Desa Sri Tanjung Kecamatan Rupat Kabupaten Bengkalis terdapat faktor pendukung di antaranya:

a). Adanya Bina Usaha yang dilakukan oleh organisasi Desa Sri Tanjung demi terlaksananya konsep bina usaha dalam pelaksanaan pemberdayaan masyarakat yang kemudian mejadi salah satu hal yang penting dalam memberikan dampak atau manfaat bagi perbaikan kesejahteraan perekonomian masyarakat. Dalam hal ini terlihat adanya pembinaan usaha masyarakat dalam bentuk usaha mikro di Desa Sri Tanjung, adanya usaha pengembangan serta peningkatan pengelolaan atas usaha-usaha yang telah ada di Desa Sri Tanjung, adanyaupaya-upaya terhadap masyarakat dalam membina usaha di bidang pertanian atau perkebunan.

b) Adanya Bina Lembaga Di Desa Sri Tanjung Kecamatan Rupat Kabupaten Bengkalis dalam pelaksanaan pemberdayaan masyarakat di lihat adanya pelaksanaan bina kelembagaan, di mana hal ini dapat di lihat melalui adanya fasilitas pendukung dalam organisasi Desa guna peningkatan atas usaha pada masyarakat Desa Sri Tanjung, adanya usaha organisasi untuk membantu pemasaran produksi pertanian perkebunan, adanya usaha yang dilakukan organisasi Desa dalam bentuk simpan pinjam untuk permodalan usaha.

\section{Faktor Penghambat}

Berdasarkan hasil penelitian terhadap Pemberdayaan Masyarakat Pada Desa Sri Tanjung Kecamatan Rupat Kabupaten Bengkalis terdapat faktor penghambat di antaranya:

a) Masih kurangnya bina lingkungan $\mathrm{Di}$ Desa Sri Tanjung Kecamatan Rupat Kabupaten Bengkalis dalam pelaksanaan pemberdayaan masyarakat. Dimana hal ini dapat dilihat masih belum adanya upaya masyarakat terhadap pelestarian lingkungan, belum adanya kesadaran masyarakat untuk melaksanakan gotong royong dalam usaha menjaga kebersihan Desa Sri Tanjung.

b) Masih kurangnya bina manusia Di Desa Sri Tanjung Kecamatan Rupat Kabupaten Bengkalis dalam pelaksanaan pemberdayaan masyarakat di lihat kurangnya pelaksanaan bina manusia. Di mana hal ini dapat di lihat melalui masih belum adanya pengembangan kapasitas individu masyarakat dalam meningkatkan pengetahuan, belum adanya pengembangan kapasitas 
Kolaborasi : Jurnal Administrasi Publik, Desember 2019 Volume 5 Nomor 3

kelembagaan, belum adanya pengembangan serta pembinaan usaha masyarakat Desa Sri Tanjung.

\section{KESIMPULAN}

Sesuai dengan uraian pada bab pembahasan, maka selanjutnya dikemukakan kesimpulan bahwa berdasarkan keempat indikator dikatakan cukup baik karena pemerintah desa sudah melaksanakan bina lembaga dan bina usaha dan Kepala Desa Perlu melakukan peningkatan pemberdayaan masyarakat yang lebih mengarah kepada pemberdayaan komunitas agar memiliki akses terhadap individu untuk mengembangkan bakat dan kemampuannya yang terpendam dalam rangka pendayagunaan sumberdaya secara berkelanjutan dalam rangka meningkatkan kesejahteraan masyarakat.

Faktor pendukung Pemberdayaan Masyarakat Pada Desa Sri Tanjung Kecamatan Rupat Kabupaten Bengkalis yaitu adanya pelaksanaan bina lembaga dan bina usaha. Sementara faktor penghambat Pelaksanaan Pemberdayaan Masyarakat Pada Desa Sri Tanjung Kecamatan Rupat Kabupaten Bengkalis yaitu bina lingkungan dan bina manusia.Sebaiknya Kepala Desa perlu melakukan pengembangan sumber daya manusia dalam pemberdayaan masyarakat supaya memiliki kemampuan dan keterampilan dengan cara mengadakan pelatihan maupun penyuluhan yang bekerja sama dengan UPTD kecamatan.

\section{UCAPAN TERIMA KASIH}

Ucapan terimakasih kepada pihak-pihak yang telah membantu sehingga penelitian ini dapat diselesaikan; aparat Desa Sri Tanjung, Yayasan STIA Lancang Kuning.

\section{DAFTAR PUSTAKA}

Adi, I.R. 2013. Intervensi Komunitas dan Pengembangan Masyarakat sebagai Upaya Pemberdayaan Masyarakat. Rajawali Pers. Jakarta

Agus Purna Irawan. 2016, Analisis Kinerja Aparatur Desa Dalam Penyelenggaraan Pemerintah Desa Di Desa Gunung Jaya Kecamatan Ladongi Kabupaten Kolaka Timur.

Halpern, D. (2005). Social Capital. Cambridge: Polity Press. pp 12

Hikmat. 2010 Manajemen pendidikan. Bandung : Pustaka Setia.

Kesi Widjajanti. 2011, Model Pemberdayaan Masyarakat

Mardikanto dan Soebiato, Sosial

Development Center, 2013.

Pemberdayaan Masyarakat.

Bandung: AlfaBeta.

Margono, Slamet. 2000. Metodologi

Penelitian Pendidikan.

Jakarta:Rineka Cipta.

Rangkuti, P.A. 2011' Komunikasi

Pembangunan dan Mekanisasi

Pertanian. IPB Pers. Bogor

Rintaka Hargita Sandhi, (2014). Partisipasi

Lembaga Pemberdayaan Masyarakat

Desa Dalam Perencanaan

Pembangunan Desa (Studi Kasus Di

Desa Karangwuni Kecamatan Rongkop) 
Rili Windiasih dan Toto Sugito.2018. Pemberdayaan Masyarakat Buruh Migran

Suharto.2018. "Pemberdayaan Masyarakat Desa Dalam Implementasi Uu Desa (Analisis Implementasi Uu No. 6 Tahun $2014 \quad$ Tentang Desa)." Prosiding Senaspolhi 1.1.

Suharto, Ambar Teguh Sulistyani, 2004, Kemitraan dan Model-Model Pemberdayaan. Yogyakarta : Graha Ilmu

Suharto, Edi. membangun masyarakat memberdayakan rakyat, bandung:Refika Aditama, 2009.

Sumodiningrat, G. (2009). Mewujudkan Kesejahteraan Bangsa Menanggulangi Kemiskinan dengan Prinsip Pemberdayaan Masyarakat. Jakarta: PT Elex Media Komputindo. pp 5-7

Suparjan dan Hempri S. Pengembangan

Masyarakat dari Pembangunan
Sampai Pemberdayaan, Aditya

Media, Yogyakarta, 2003

Syahyuti'. 2006. Tiga Puluh Konsep Penting dalam Pembangunan Pedesaan dan Pertanian' Bina Rena Pariwara. Jakarta

Payne, M. (1997). Modern Social Work Theory. Second edition. London: Macmillan Press Ltd. pp. 266

World Bank. 2001. Attacking poverty with a three-pronged strategy. World Bank Policy and Research Bulletin Vol 11 No.4/Vol 2 No.1 Oktober-Desember 2000/ Januari-Maret 2001

Undang Undang Republik Indonesia No 6 Tahun 2014. Tentang Desa

Perda Kabupaten Bengkalis No. 12 Tahun 2012 tentang pembentukan desa, 